\title{
常時微動による地盤分類とそれに基づく強震時の地盤特性に関する予備的分析 SITE CLASSIFICATION BY MICROTREMORS AND PRELIMINARY ANALYSIS OF
SITE AMPLIFICATION DURING STRONG SHAKING FOR DIFFERENT SITE CLASSES
}

野木 淑裕*, 翠川三郎**, 三浦弘之*** Yoshihiro NOGI, Saburoh MIDORIKAWA and Hiroyuki MIURA

\begin{abstract}
This paper examines site amplification based on NEHRP site classification using strong motion records of the 2011 off the Pacific coast of Tohoku Earthquake. We classify the strong motion sites into class B to $\mathrm{E}$ using the $\mathrm{H} / \mathrm{V}$ spectral ratio of microtremors. Site amplifications are derived from the ratio of the average spectra for classes $\mathrm{C}, \mathrm{D}$ and $\mathrm{E}$ with respect to that for class $\mathrm{B}$. The amplification of a class with slower $\mathrm{V}_{\mathrm{S} 30}$ is larger at long periods and smaller at short periods. The different amplifications derived from the strong motion records and from weak motion records indicate effects of nonlinear soil response.
\end{abstract}

Keywords : Site Amplification, Site Classification, Microtremor, Strong Motion Record, The 2011 off the Pacific coast of Tohoku Earthquake 地盤特性，地盤分類，常時微動，強震記録，2011 年東北地方太平洋沖地震

\section{1. はじめに}

地震動は表層地盤によって増幅されることが知られており，地盤 特性を正確に評価することは, 建築物への入力地震動を評価する上 で重要である。日本の建築基準法では地盤特性を評価する指標とし

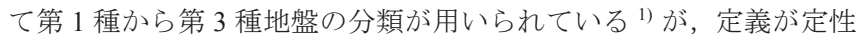
的で客観性に欠ける面がある.このような定性的な地盤分類に対し ては評価者毎にかなり異なった判別がされるという問題も指摘され ている ${ }^{2)}$ 。一方，地盤特性を表す簡便かつ定量的な指標として $\mathrm{V}_{\mathrm{S} 30}$ （地表から深さ $30 \mathrm{~m}$ までの平均せん断波速度）が有効であることが 指摘されている ${ }^{3)-7)}$. アメリカの耐震基準で用いられる NEHRP ${ }^{8)}$ の 地盤分類は $\mathrm{V}_{\mathrm{S} 30}$ に基づくより客観的なもので, Table 1 に示すように $\mathrm{A}$ から $\mathrm{E}$ の順で岩盤から軟弱地盤の 5 分類となっており, 各地盤分 類に対する地盤増幅度が規定されている. これに類似の地盤分類は ヨーロッパの耐震基準にも採用され 9)，国際標準となりつつある。 ここでの 5 分類の $\mathrm{V}_{\mathrm{S} 30}$ の区切りが日本の地盤に対しても最適である かどうかは議論の余地があろうが，海外と日本の強震記録を地盤特 性に関する共通の尺度で分析・比較しようとすると，この地盤分類 に対する地震動の地盤特性について検討することは重要と考えられ る.

NEHRP の地盤分類は客観的ではあるが，対象地点のせん断波速 度構造が必要となり, 強震記録の分析に各強震観測点の地盤分類を
用いようとした場合に，この地盤分類が利用できる場合は限られて しまう。そこで，松岡ら ${ }^{10)}$ による微地形区分から $V_{\mathrm{S} 30}$ を推定する 手法が用いられる場合がある。しかし，この推定值は各地形分類の 平均值で，かなりのバラツキを伴い，強震観測点の地盤条件を正確 に反映できない恐れもある.

地盤条件を把握する手段の 1 つとして常時微動があり, Kanai and Tanaka ${ }^{11)}$ は常時微動から旧建築基準法の地盤種別に分類する方法 を提案している。この手法では常時微動の最大振幅と卓越周期を用 いているが, 中村 ${ }^{12)}$ は常時微動の上下動に対する水平動のスペクト ルの比（H/V スペクトル比）を用いると時間変動の影響を受けずに 地盤特性をより正確に把握できることを示している。この $\mathrm{H} / \mathrm{V}$ スペ クトル比は地盤特性に応じて地域を区分する際にも広く用いられて いる ${ }^{13)}$ 。これらのことから, 常時微動の $\mathrm{H} / \mathrm{V}$ スペクトル比を用い

Table 1 Relationship between NEHRP site classification and $\mathrm{V}_{\mathrm{S} 30}$

\begin{tabular}{cc}
\hline Site Class & $\mathrm{V}_{\mathrm{S} 30}(\mathrm{~m} / \mathrm{s})$ \\
\hline $\mathrm{A}$ & $1500<\mathrm{V}_{\mathrm{S} 30}$ \\
$\mathrm{~B}$ & $760<\mathrm{V}_{\mathrm{S} 30} \leqq 1500$ \\
$\mathrm{C}$ & $360<\mathrm{V}_{\mathrm{S} 30} \leqq 760$ \\
$\mathrm{D}$ & $180<\mathrm{V}_{\mathrm{S} 30} \leqq 360$ \\
$\mathrm{E}$ & $\mathrm{V}_{\mathrm{S} 30} \leqq 180$ \\
\hline
\end{tabular}

" 東京工業大学大学院総合理工学研究科人間環境システム専攻 大学院生 (研究当時)

** 東京工業大学大学院総合理工学研究科人間環境システム専攻 教授. 工博

*** 広島大学大学院工学研究科建築学専攻 准教授・博士 (工学)
Formerly Grad. Stud., Dept. of Built Environment, Interdisciplinary Graduate School of Science and Technology. Tokyo Institute of Technology

Prof., Dept. of Built Environment, Interdisciplinary Graduate School of Science and Technology, Tokyo Institute of Technology, Dr.Eng.

Assoc. Prof., Dept. of Architecture, Graduate School of Engineering, Hiroshima Univ., Dr.Eng. 
ることによって地盤分類を評価する精度が向上する可能性がある.

2011 年東北地方太平洋沖地震は国内の観測史上最大の地震であ り，様々な機関により大振幅の強震記録が多数得られた ${ }^{14)}$ 。これら の記録は, 従来十分には検討できなかった大振幅時の地盤特性と地 盤分類の関係について, より詳細な評価を可能ならしめ, 強震時の 地盤特性を検討する上で貴重なデータであると言える。そこで，本 研究では, 常時微動を用いて NEHRP の地盤分類をより良い精度で 推定する手法を構築し, 東北地方太平洋沖地震の強震記録が得られ た観測点での NEHRP の地盤分類を推定する.さらに, NEHRP の地 盤分類に対する強震時の地盤特性についての予備的な分析として, 東北地方太平洋沖地震の強震記録から地盤分類毎の平均スペクトル を求め, そのスペクトル比から各地盤分類での平均的な地盤増幅度 を近似的に評価する。なお，本研究の対象周期は $0.1 〜 2$ 秒であり， 表層地盤の地盤増幅を対象としている.

\section{2. 対象とする強震記録}

2.12011 年東北地方太平洋沖地震の強震記録

渥美ほか ${ }^{14)}$ は, 防災科学技術研究所の K-NET と KiK-net, 気象庁, 自治体ネットワーク, 国土交通省, 港湾空港技術研究所, 建築研究 所, 東北工業大学によって東北地方太平洋沖地震で観測された 2759 記録を整理している.本研究では文献 14)で対象とした記録 ${ }^{15)-21) ~ に, ~}$ 東日本旅客鉄道, 東日本高速道路, 東北大学, 土木研究所による 159 記録 ${ }^{21)-23)}$ を追加し, 計 2918 記録からなるデータセットを作成した. なお，これらの記録はいずれも自然地盤上もしくはそれと同等であ るとみなせる位置（低層建物内部 1 階など）におけるものである.

\section{2 対象とする強震観測点}

本研究では, 強震時の地盤特性を検討するため, 前述の 2918 記録 のうち, 震度 6 弱以上の地域を概残包含する岩手・宮城・福島・栃 木・茨城の 5 県における 467 観測点で得られた記録を対象とする.

Fig.1 に対象地点の位置を示す. 対象地点は海岸線と概ね平行に分布 し, この地震の断層面からの距離に大きな違いがない. 観測機関ご との地点数は, 自治体の観測点が 180 地点と約 4 割を占め, K-NET および KiK-net の観測点が 2 割強を占める。これらの観測点のうち PS 検層が得られているものは 92 地点で, 残りの 375 地点では得ら れていない。 なお, KiK-net 観測点については浅い部分で測定間隔 が疎らと考えられるデータがみられたため, 深さ $30 \mathrm{~m}$ までに 2 層以 下のPS 検層データは除外した。

\section{3 強震観測点での常時微動計測の概要}

対象地点のうち 101 地点では常時微動計測が行われており 24), 残 る 366 地点で計測を行なった. 用いた微動計は Fig.2 に示すように 周期 0.05 秒から 2 秒の範囲で速度に対して概ね平坦な特性を持つ. 常時微動の解析においては，車の振動などによって振幅が大きくな った記録を避けた 20.48 秒間を 3 区間選び，フーリエスペクトルを 算出し， $0.3 \mathrm{~Hz}$ の Parzen ウィンドウで平滑化を行なった。 サンプリ ングは $100 \mathrm{~Hz}$ である. なお，地盤の増幅率が知られている地点で, 周期 0.1 秒から 2 秒の範囲で地盤の増幅率と微動の $\mathrm{H} / \mathrm{V}$ スペクトル 比を比較した結果, Parzen ウィンドウの幅が $0.3 \mathrm{~Hz}$ の場合の微動の $\mathrm{H} / \mathrm{V}$ スペクトル比が最もよい相関を示すこと ${ }^{25)}$ から, この值を採用 した. 水平動については水平 2 成分の平均を用いて, $\mathrm{H} / \mathrm{V}$ スペクト ル比を算出し, 3 区間の平均值を各地点の H/V スペクトル比とした。

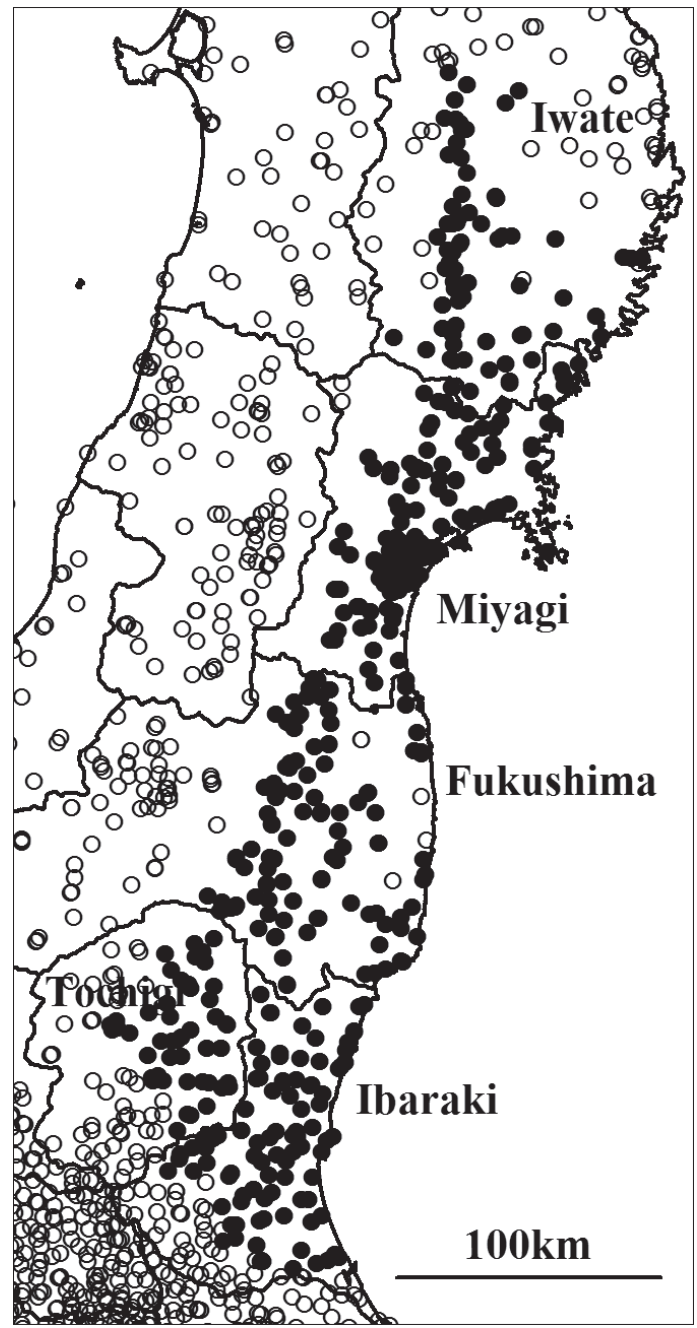

Fig.1 Location of target sites (solid circles)

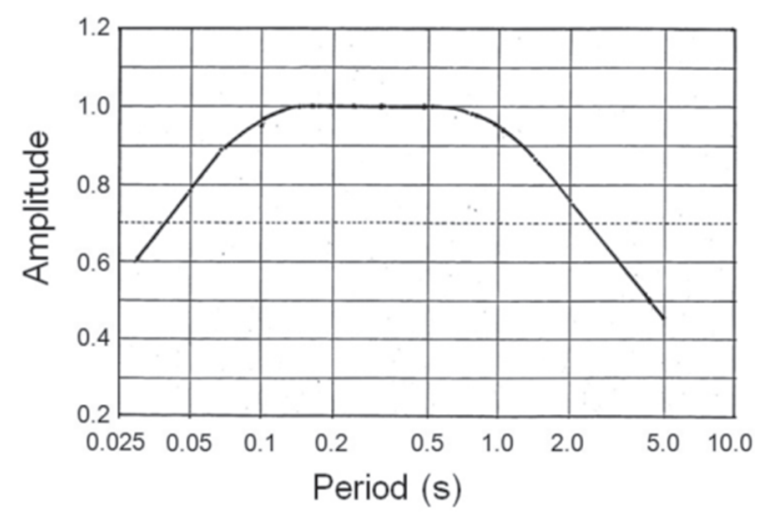

Fig.2 Over-all response of microtremor instrument

また，特定のノイズのない 20.48 秒間の 3 区間の平均を用いれば安 定した結果が得られることが指摘されている ${ }^{26)}$.

\section{3. 常時微動による地盤分類}

\section{1 地盤分類手法}

$\mathrm{V}_{\mathrm{S} 30}$ に基づく地盤分類と常時微動の $\mathrm{H} / \mathrm{V}$ スペクトル比との対応か ら，常時微動から地盤分類を行う手法を検討した，検討には，対象 地点のうち PS 検層がある観測点 92 地点を用いた。この中で地盤分 
類 $\mathrm{E}$ の観測点が少なかったため, 横浜市内のPS 検層が得られてい る 12 地点を追加した. なお, 対象地点に地盤分類 $\mathrm{A}$ の地点は存在 しなかったため, 地盤分類 $\mathrm{A}$ は検討対象外とした。岩盤上の観測点 である KiK-net 観測点での PS 検層結果からも地盤分類 A の観測点 はほとんどみられず 27), 地盤分類 A の地点は非常に希と判断され ることから，地盤分類 $\mathrm{A}$ を検討対象外にしても実用上大きな問題は ないと考えられる.

まず地盤分類ごとの傾向を確認するために，観測点の地盤分類ご とに, 常時微動による $\mathrm{H} / \mathrm{V}$ スペクトル比の平均スペクトルと標準偏 差を算出した（Fig.3）. 硬い地盤分類 B では H/V スペクトル比の振 幅に卓越がみられず全体的に平坦な傾向があるのに対し, 地盤分類 $\mathrm{C}$ から $\mathrm{E}$ 一と地盤の $\mathrm{V}_{\mathrm{S} 30}$ が遅くなるにつれて, 卓越周期が長周期側 にみられ, 卓越周期でのスペクトル比が増大寸る傾向がみられる. これらの特徵に基づき, 常時微動から地盤分類を行なう基準を以下 の手順で定めた. なお微動の $\mathrm{H} / \mathrm{V}$ スペクトルに同等の振幅を持つピ ークが複数現れ, どちらのピークを採用すべきか判断できない場合 も少なくないことから, 分類基準として卓越周期やそこでの比の值 は用いなかった。

(1)地盤分類 $\mathrm{E}$ の抽出

地盤分類 $\mathrm{E}$ の $\mathrm{H} / \mathrm{V}$ スペクトル比が長周期側で卓越することから, $\mathrm{H} / \mathrm{V}$ スペクトル比における短周期と長周期の比（長周期の平均值／ 短周期の平均值）を取ることにより地盤分類 $\mathrm{E}$ を抽出する. 平均ス ペクトルの形状から短周期・長周期それぞれ複数の周期带を仮定し て検討した結果, Fig. 4 に示寸ように, 短周期として周期 $0.1 \sim 0.3$ 秒 の平均に対する, 長周期として周期 $0.6 \sim 1.2$ 秒の平均の比を用いる 時に最も抽出しやすくなり, 境界值を 2.7 とすることが最適である と判断した. この境界值の時, 地盤分類 $\mathrm{E} の 23$ 地点中 1 地点と地 盤分類 $\mathrm{B} \sim \mathrm{D}$ の 81 地点中の 3 地点が他分類に属すると誤判断される ものの正解率は $96 \%$ である.

(2)地盤分類 B $の$ 抽出

Fig.3 の H/V スペクトル比より, 地盤分類 B のスペクトル比は C

や $\mathrm{D}$ に比べて平坦であり, 各周期でのスペクトル比の分散が小さい ことが予想できる。複数の周期帯を仮定して分散を算出した結果, Fig.5 に示すように周期 0.1〜2 秒の範囲での分散を用いる場合に抽 出しやすく，境界值を 0.007 とした．この境界值の時，地盤分類 $\mathrm{B}$ は全て正しく分類され, 地盤分類 $\mathrm{C}$ では 1 点が誤判断されるものの

B Ave $\pm \sigma$

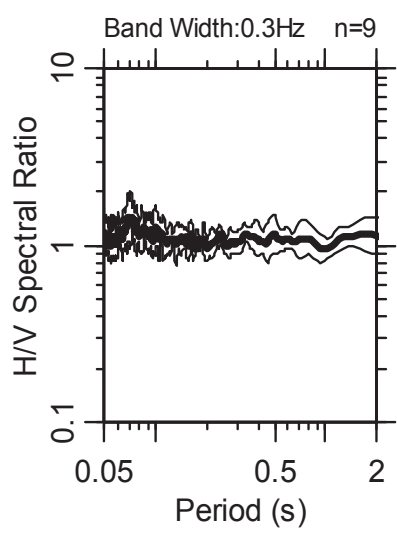

D Ave $\pm \sigma$

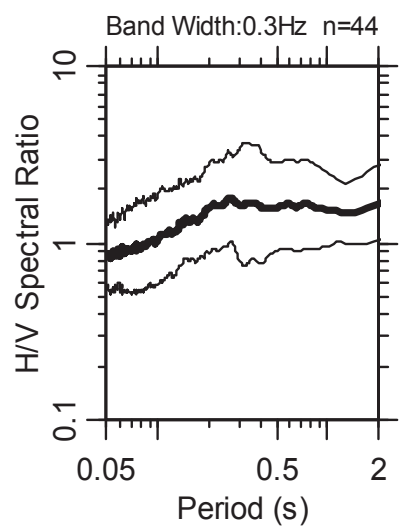

Fig.3 Average and standard deviation of $\mathrm{H} / \mathrm{V}$ spectra
C Ave $\pm \sigma$

Band Width:0.3Hz n=28

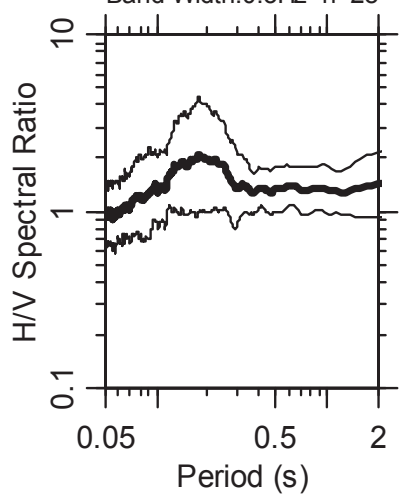

E Ave $\pm \sigma$

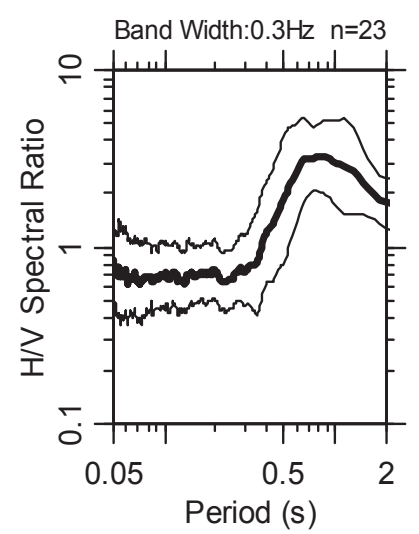

Ave(0.6 1.2s) / Ave(0.1 0.3s)

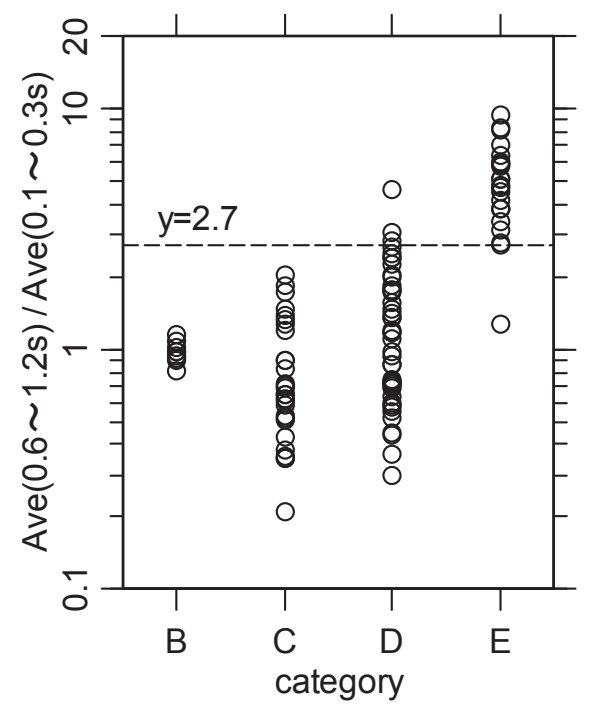

Fig.4 Criterion to classify class $\mathrm{E}$

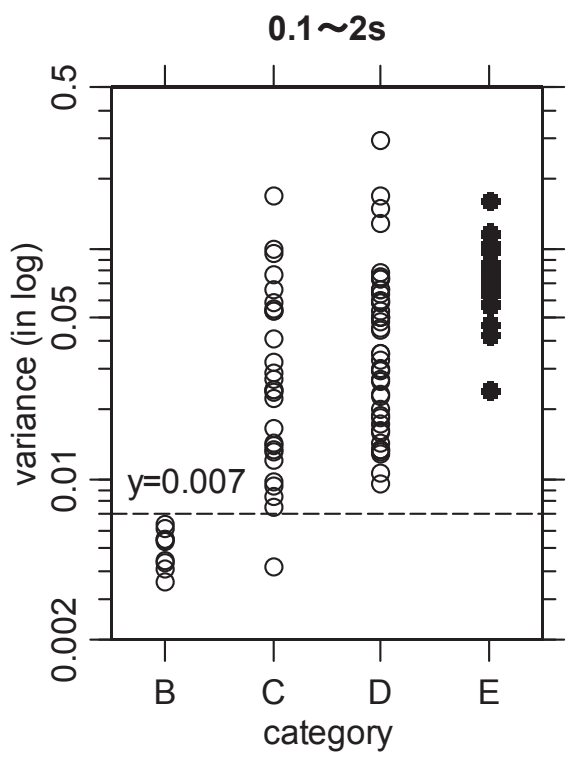

Fig.5 Criterion to classify class B
Ave(0.3 0.8s) / Ave(0.1 0.2s)

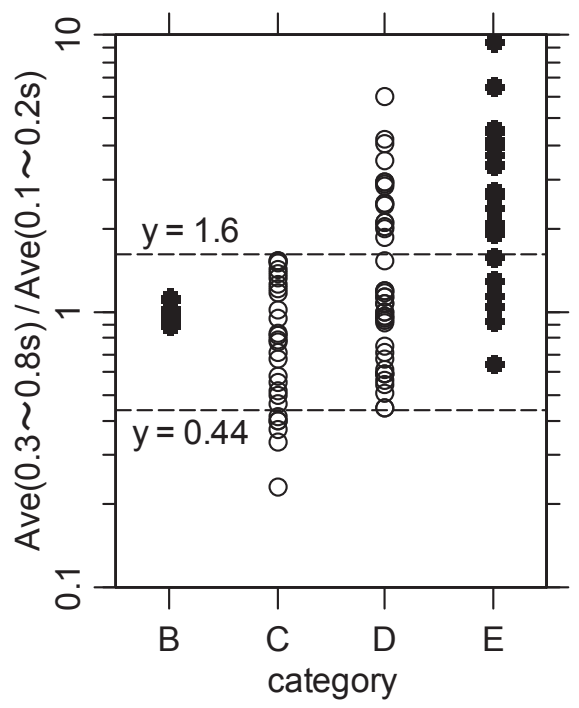

Fig.6 Criterion to classify classes $\mathrm{C}$ and D 
Table 2 Comparison of classifications by microtremor and by PS-logging data

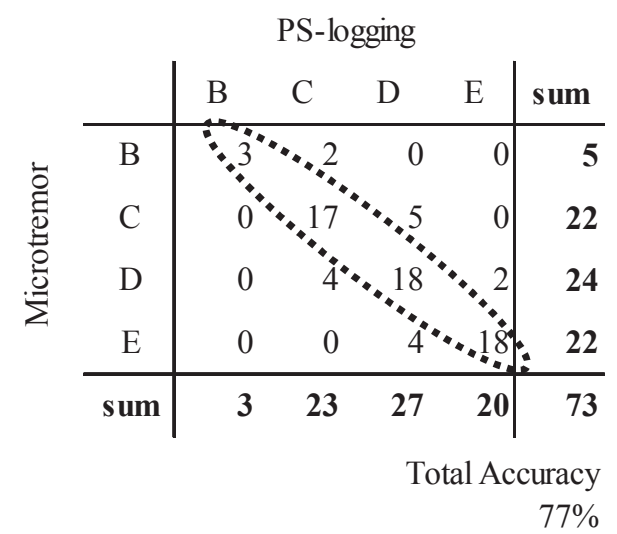

Table 3 Comparison of classifications by geomorphologic data and by PS-logging data

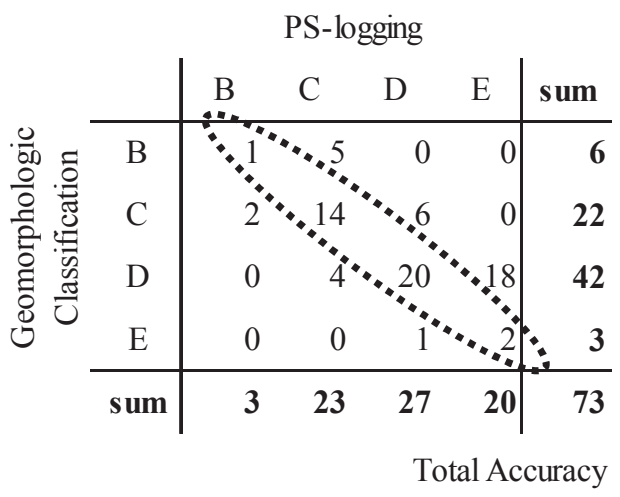

$51 \%$

正解率は $99 \%$ である。

(3)地盤分類 C と D の区別

Fig.3 において, 地盤分類 C で $0.1 \sim 0.3$ 秒の付近でスペクトル比の 卓越がみられ, 地盤分類 D では 0.3 秒付近までスペクトル比が増加 し長周期側でほぼ平坦となっていることに基づいて, (1) と同椂に $\mathrm{H} / \mathrm{V}$ スペクトル比の短周期と長周期の比を用いて分類を行なうこと とした。

複数の周期帯で検討した結果, Fig.6 に示すように周期 $0.1 \sim 0.2$ 秒 の平均に対する $0.3 \sim 0.8$ 秒の平均の比を用いた場合に地盤分類 $\mathrm{C}$ と D が最も分かれているようにみられた。それでも重複する部分がか なり多く,「C に分類できる範囲」「D に分類できる範囲」「C と D の混合帯」の 3 つに分類することとし, 長周期 / 短周期の比が 0.44 以下で地盤分類 $\mathrm{C}$ に, 比が 1.6 以上で地盤分類 $\mathrm{D}$ に分類することと した。 0.44 から 1.6 の間の「C と D の混合帯」については常時微動 から分類することが困難であると判断し， $250 \mathrm{~m}$ メッシュの微地形 データによる $\mathrm{V}_{\mathrm{S} 30}$ の推定值 ${ }^{28)}$ から地盤分類 $\mathrm{C}$ ないし $\mathrm{D}$ に分類する こととした

\section{2 常時微動を用いた手法と既往の地盤分類手法による推定精度 の比較}

前節で定めた手法による地盤分類の推定精度を確認するため, 前 節の検討で用いていない別の 73 地点でのデータを用いて, PS 検層 からの $\mathrm{V}_{\mathrm{S} 30}$ による地盤分類を正解として, 本手法による常時微動か

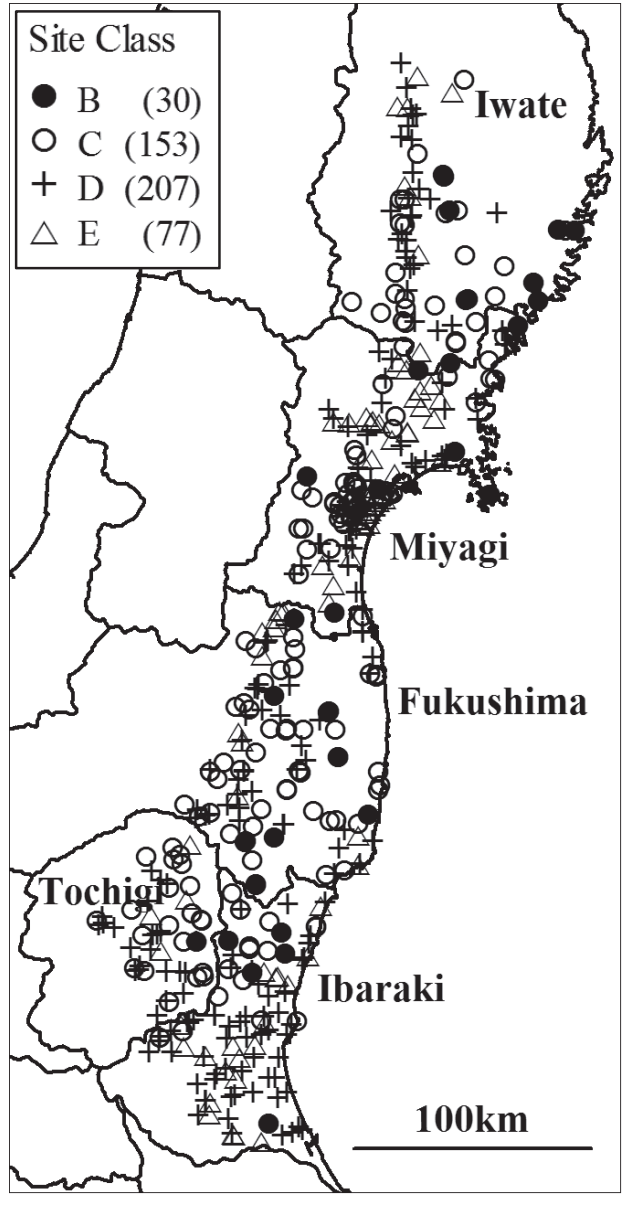

Fig.7 Spatial distribution of site classes

Table 4 Average and standard deviation of ground motion indexes at class $B$ sites

\begin{tabular}{crr}
\hline Index & Average & $\begin{array}{r}\text { Standard } \\
\text { Deviation }\end{array}$ \\
\hline Peak Ground Acceleration $(\mathrm{cm} / \mathrm{s} / \mathrm{s})^{*}$ & 452 & 189 \\
Peak Ground Velocity $(\mathrm{cm} / \mathrm{s})^{*}$ & 24 & 9 \\
JMA Seismic Intensity Scale & 5.2 & 0.3 \\
\hline
\end{tabular}

*peak ground acceleration and velocity show larger value of 2 horizontal components.

らの地盤分類と松岡ら ${ }^{10)}$ の微地形区分を用いた地盤分類の精度を 比較した。これら 73 地点は北海道, 北陸, 関東, 中国など全国各地 に分布している. Table 2 に示すように常時微動を用いた本研究の分 類手法では，PS 検層に基づく分類と同じ分類となる正解率が $77 \%$ となった. 一方, Table 3 に示すように微地形データによる $\mathrm{V}_{\mathrm{S} 30}$ 推定 值からの地盤分類の正解率は $51 \%$ であり, 本手法により分類精度が 向上することを確認した。なお，前節の検討で用いた 104 地点のデ ータを用いて同様の検討をしたところ, 本手法による正解率は $75 \%$, 微地形データによる正解率は $55 \%$ だった。

\section{4. 地盤分類ごとのスペクトル特性と地盤増幅率}

対象地点での地盤分類を前述の方法で行い，地盤分類毎のスペク トル特性について検討する，K-NET や KiK-net などの PS 検層デー タが得られている 92 地点についてはそれに基づく地盤分類を用い 

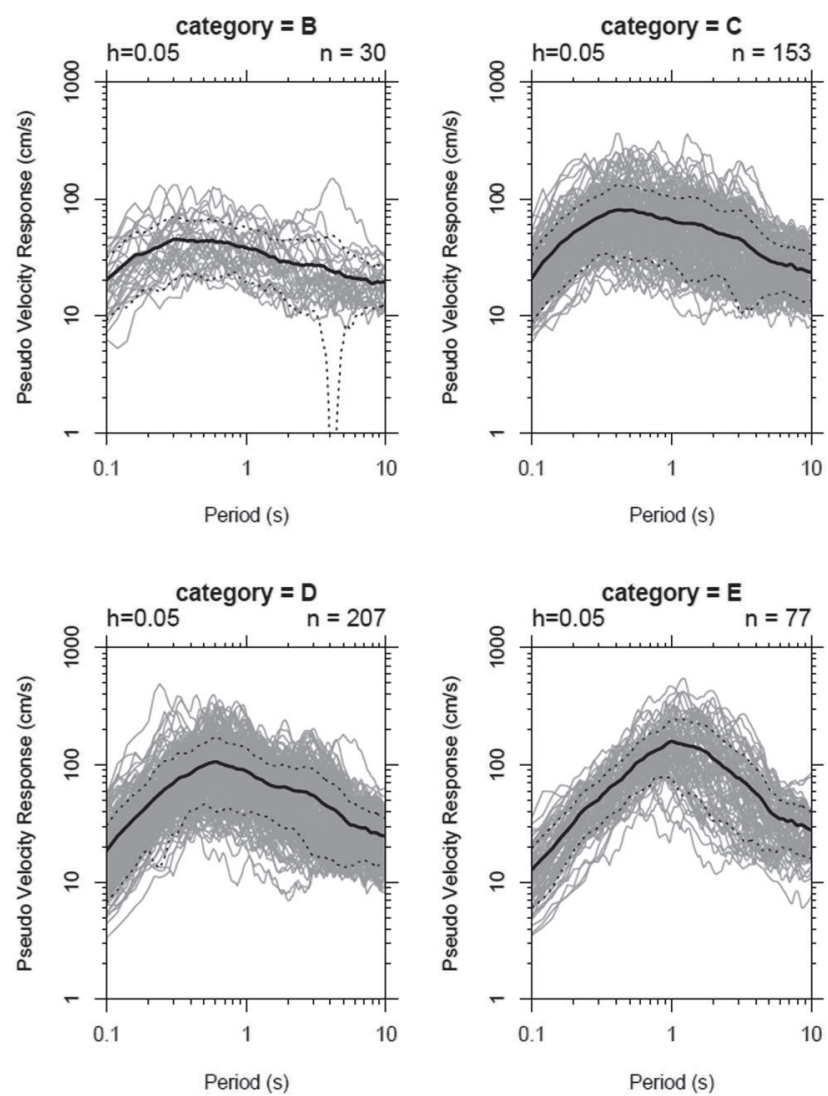

Fig.8 Pseudo-velocity response spectra and average spectra with standard deviation for different site class

る. なおデータの深さが $30 \mathrm{~m}$ に満たない場合は, 翠川・野木 ${ }^{27)} の$ 手法により浅いデータから推定した $\mathrm{V}_{\mathrm{S} 30}$ を用いた。

Fig.7 に示す各地盤分類の地理的な分布をみると, 特定地域にかた よることなくおおむ䄪均一に分布していることがわかる. 分類 D が 最も多く 4 割強を占め, 次いで分類 C が多い. 対象とした地域で得 られた観測記録は, Table 4 に示すように, 最も硬い地盤分類 B では 最大加速度および計測震度の平均はそれぞれ約 $450 \mathrm{~cm} / \mathrm{s} / \mathrm{s}$ および 5.2 であり, 強震時の記録といえる.また標準偏差はそれぞれ約 $190 \mathrm{~cm} / \mathrm{s} / \mathrm{s}$ および 0.3 と比較的小さく, 各地点での地震動レベルの差 はあまり大きなものではないものと考えられる.

Fig.8 に地盤分類ごとの速度応答スペクトルとその平均スペクト ルを標準偏差 (点線) とともに示寸. なお, 対象とする周期範囲で は強震計の特性は平坦であることから計器の特性補正は行っていな い. 地盤分類 B ではスペクトルが比較的平坦であるのに対して地盤 分類 $\mathrm{C}$ から $\mathrm{E}$ 一と $\mathrm{V}_{\mathrm{S} 30}$ の遅い地盤分類となるにつれて卓越周期が長 周期側にみられ，卓越周期でのスペクトル比が増大寸る傾向がみら れる. また地盤分類 $\mathrm{C}$ と $\mathrm{D}$ のスペクトルは, 地盤分類 $\mathrm{B}$ や $\mathrm{E}$ と比 べると卓越周期や振幅が類似している. このことは地盤分類 $\mathrm{C}$ と $\mathrm{D}$ のVs30 の区切りについては再検討する必要があることを示唆して いるかもしれないが，ここではこの問題は取り扱わない.

この地震の強震動は複数の強震動生成域から放射されたものと指 摘されており ${ }^{29)}$, 各強震動生成域との位置関係に応じて各地点で基 盤に入射するスペクトル特性は厳密には異なるものと考えられる. しかしながら, 観測された最大加速度や最大速度を強震動生成域か

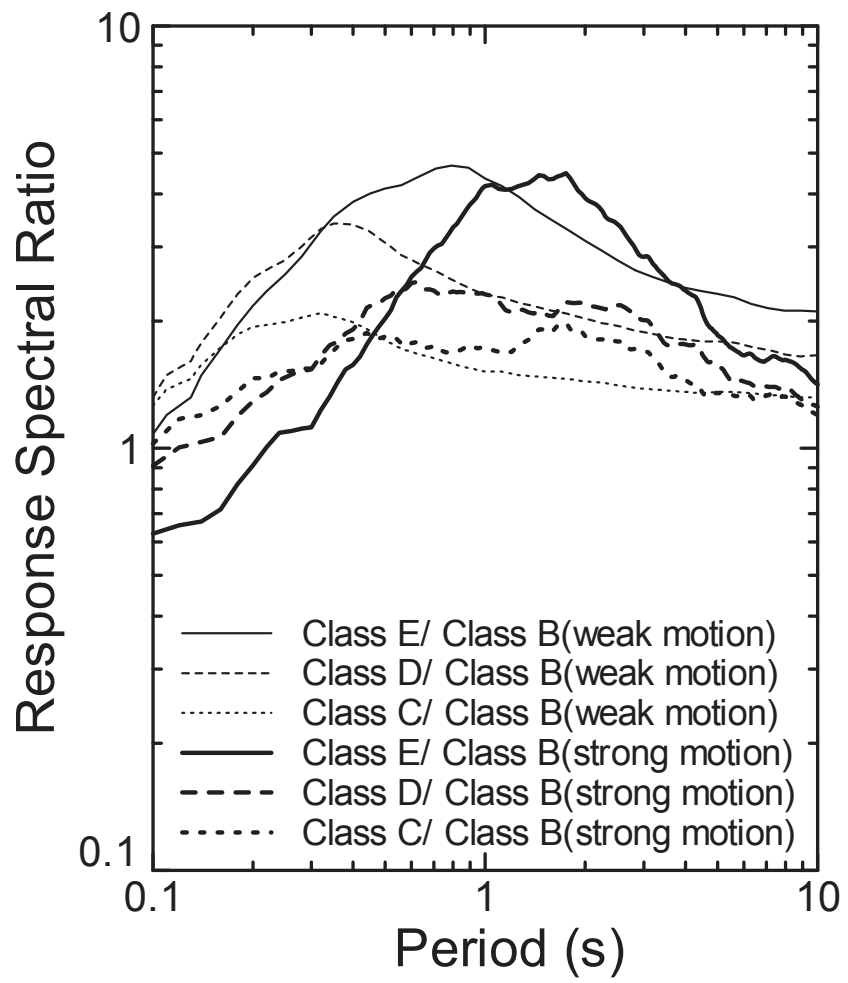

Fig.9 Comparison of site amplification from strong motion with that from weak motion

らの距離で整理すると比較的小さなバラツキでまとまっており ${ }^{30)}$, 本研究で対象とした観測点までの距離は 80\%弱が 70〜 $110 \mathrm{~km}$ と限ら れた範囲に分布し距離減衰の影響も比較的小さいものと考えられる。 また, 前述したように硬い地盤分類 B の観測点の最大加速度や震度 に大きな違いがみられない。これらから，第一近似として，対象地 域では基盤に入力される地震動の強さは類似しており，地盤分類 $\mathrm{B}$ の平均スペクトルが基盤でのスペクトル特性とみなしても大きな誤 りはおかさないものと考えられる。 そこで, これで基準化した地盤 分類 C から $\mathrm{E}$ のスペクトル比を除することで, 震源特性の影響を除 去して，近似的に地盤の増幅率を抽出することとした．

地盤分類 $\mathrm{B}$ の平均スペクトルに対する地盤分類 $\mathrm{C}$ から $\mathrm{E}$ の平均ス ペクトルの比から求めた地盤分類 C から E の増幅率を Fig.9 (太線) に示す．地盤分類 $\mathrm{C}$ の増幅率は対象周期全体で比較的平坦であるの に対して地盤分類 $\mathrm{E}$ では振幅が大きくなる. 地盤分類 C と D は増幅 率が 2 程度であり, これらの間の差は地盤分類 $\mathrm{E}$ との差に比べて小 さい，短周期において， $\mathrm{V}_{\mathrm{S} 30}$ の遅い地盤分類ほど増幅率が 1 より小 さくなり，地盤分類 $\mathrm{E}$ の増幅率は周期 0.1 秒で 0.6 程度である。一 方，周期 1〜2 秒の長周期においては 5 程度まで増大する.

本研究では, 強い摇れの記録を対象としており, 前述したように, 地盤分類 B の地点での最大加速度が $450 \mathrm{~cm} / \mathrm{s} / \mathrm{s}$ 程度の振幅レベルで の地盤増幅率を Fig.9 の太線は表している。一方，山口・翠川 ${ }^{31)}$ は 非線形性の影響のない弱い摇れの観測記録 $($ 最大加速度で $100 \mathrm{~cm} / \mathrm{s} / \mathrm{s}$ 程度以下）を用いて地盤増幅率と $\mathrm{V}_{\mathrm{S} 30}$ の関係式を示している。この 手法においては NEHRP の地盤分類ではなく $V_{\mathrm{S} 30}$ をパラメータとし て検討されている. 本研究で用いた NEHRP の各地盤分類の $\mathrm{V}_{\mathrm{S} 30}$ の 
平均値を求めてみると, 地盤分類 $\mathrm{B}$ から E での平均値はそれぞれ約 900，450，270，140m/s であることから，この值を用いて地盤分類 $\mathrm{B}\left(\mathrm{V}_{\mathrm{S} 30}=900 \mathrm{~m} / \mathrm{s}\right)$ に対する地盤分類 $\mathrm{C}$ から $\mathrm{E}$ の増幅率を求めた.

Fig.9 の細線で弱震時の増幅率を示す. これをみると, 地盤分類 C の増幅率は比較的平坦で, 地盤分類 $\mathrm{D}, \mathrm{E}$ と $\mathrm{V}_{\mathrm{S} 30}$ が遅くなるにつれ て, 卓越周期が延び, 増幅率の值も増大している.これに比べて, 本研究の強震時の増幅率は, 短周期で小さく, 特に地盤分類 $\mathrm{E}$ でそ の差が顕著である. 一方, 周期 0.5 秒前後より長周期では, 本研究 の方が大きく, 卓越周期も長くなっている. 地盤の非線形性により, 地盤の卓越周期が延び，短周期では増幅が低下寸ることが知られて いる ${ }^{32)}$.このことが東北地方太平洋沖地震の強震記録にもみられる ことは既に指摘されており, 地盤の非線形性の影響で本研究の対象 地域では地盤の卓越周期が 2 倍弱伸びていること ${ }^{33)}$ や, 振幅レベ ルが増大寸るにつれて短周期での地盤の増幅率が低下すること ${ }^{34)}$ が指摘されている. 弱震時と本研究の結果の違いはこれらと調和的 で，両者の違いは地盤の非線形性の影響と考えられる.

このような非線形性の影響を耐震基準での地盤増幅に考慮するこ とは土の室内実験に基づく地盤応答解析に基づいて行われている ${ }^{35)}$ が, 実際の観測記録の結果に基づく妥当性の検証は十分ではなく ${ }^{36)}$, 本研究の結果はそのための基礎資料として位置付けられる.ただし, 本研究の結果は, 地盤分類 B の地点での最大加速度が $450 \mathrm{~cm} / \mathrm{s} / \mathrm{s}$ 程 度の振幅レベルでの平均的な結果で, 振幅レベル毎に詳細に検討さ れた結果ではない。今後, 観測記録から振幅レベル毎に地盤増幅率 の分析を進め, 地盤増幅率の振幅依存性に関する定量的な評価に結 びつけていきたい.

\section{5. 結論}

東北地方太平洋沖地震の強震記録を用いて, NEHRP の地盤分類に 基づいて地盤特性について検討した。地盤の PS 検層データがない 強震観測点が多いことから, 常時微動を用いて地盤分類を行なう手 法を提案し, 既往の微地形データからの推定結果と比べて地盤分類 の判別精度が向上することを示した。この地盤分類を用いて大振幅 時の強震記録の速度応答スペクトルを整理し, 地盤分類 $\mathrm{B}$ を基準と したスペクトル比から強震時の地盤分類毎の地盤増幅率を近似的に 求めた。 既往研究による弱震時の増幅率と比較すると, $\mathrm{V}_{\mathrm{S} 30}$ の遅い 地盤ほど卓越周期が伸び, 短周期では増幅率が低下しており, 強震 時の地盤の非線形性の影響を確認した. 今後, 基盤地震動の地域性 や入力レベルの影響についてより詳細な分析を行い, 地盤増幅率の 振幅依存性に関する定量的な評価に結びつけていきたい.

\section{謝辞}

本研究では防災科学技術研究所, 気象庁, 自治体, 国土交通省, 港湾空港技術研究所, 建築研究所, 東北工業大学, 東北大学, JR 東 日本, NEXCO 東日本の強震記録および防災科学技術研究所の地盤 データを使用した。本研究の一部は JSPS 科学研究費補助金（No. 23241054）によった。記して謝意を表する.

\section{参考文献}

1) 加藤研一: 改正建築基準法に至る地震外力の考え方, 第 30 回地盤震動シ ンポジウム資料集，pp.13-23，2002.10.

2) Yoshida, N. and Iai, S.: Nonlinear Site Response And Its Evaluation And
Prediction, Proc. 2nd International Symposium on the Effect of Surface Geology on Seismic Motion, Yokosuka, Japan, pp. 71-90, 1998.

3) Borcherdt, R. D., Gibbs, J. F. and Fumal, T. E.: Progress on ground motion predictions for the San Francisco Bay region, California, U.S. Geol. Survey Cir. 807, pp.13-25, 1979.

4) 翠川三郎, 松岡昌志, 作川孝一: 1987 年千葉県東方沖地震の最大加速度 . 最大速度にみられる地盤特性の評価, 日本建築学会構造系論文報告集, No.442, pp.71-78, 1992.12 .

5) 末冨岩雄, 石田栄介, 磯山龍二, 後藤洋三 : 地盤の平均 $\mathrm{S}$ 波速度による 地震動強度指標の非線形増幅度評価法について, 土木学会地震工学論文集, Vol.28，論文番号 122, pp.1-8，2003.12.

6) 藤本一雄, 翠川三郎 : 近接観測点ペアの強震記録に基づく地盤増幅度と 地盤の平均 $\mathrm{S}$ 波速度の関係, 日本地震工学会論文集, Vol.6, No.1, pp.11-22, 2006.2.

7) Borcherdt, R.: $V_{\mathrm{S} 30}$ - A Site-Characterization Parameter for Use in Building Codes, Simplified Earthquake Resistant Design, GMPEs, and ShakeMaps, Proceedings of the $15^{\text {th }}$ World Conference on Earthquake Engineering, Paper \# 173, pp.1-10, 2012.9 .

8) Building Seismic Safety Council (BSSC): NEHRP Recommended Provisions for Seismic Regulations for New Buildings and Other Structures, Part 1 (Provisions) and Part 2 (Commentary), Report prepared for the Federal Emergency Management Agency, Washington, D.C., 2004.

9) Bisch, P., Carvalho, E., Degee, H., Fajfar, P., Fardis, M., Franchin, P., Kreslin, M., Pecker, A., Pinto, P., Plumier, A., Somja, H. and Tsionis, G.: Eurocode 8: Seismic Design of Buildings - Wordked examples, JRC Scientific and Technical Reports, 2012

10) 松岡昌志, 若松加寿江, 藤本一雄, 翠川三郎：日本全国地形・地盤分類 メッシュマップを利用した地盤の平均 $\mathrm{S}$ 波速度分布の推定, 土木学会論文 集, No.794/I-72, pp.239-251, 2005.7.

11) Kanai, K. and Tanaka, T.: On Microtremors VIII, Bulletin of the Earthquake Research Institute, Vol. 39, pp. 97-114, 1961.3.

12) 中村豊 : 常時微動計測に基づく表層地盤の地震動特性の推定, 鉄道総研 報告, Vol. 2, No. 4, pp.18-27, 1988.4 .

13) 中村仁, 福和伸夫, 高橋広人, 飛田潤, 堀啓輔 : 常時微動計測に基づく 名古屋市域の地盤震動特性と基盤深さの推定に関する研究, 構造工学論文 集, 第 46B 巻, pp.413-421, 2000.3.

14) 渥美知宏, 翠川三郎, 三浦弘之, 先名重樹, 藤原広行 : 2011 年東北地方 太平洋沖地震で観測された強震記録とその強さについて, 日本建築学会大 会学術講演梗概集, B-2, pp.173-174, 2013.8 .

15) 気象業務支援センター：加速度データ（95 型震度計波形データ） 2011 年 CD-ROM, 2012.5.

16) 鷹野澄, 䋶纈一起 : 首都圈強震動総合ネットワーク(SK-net), 東日本大 震災合同調査報告 共通編 1 地震・地震動, pp.96-99, 2014.3 .

17) 功刀卓, 青井真, 鈴木亘, 中村洋光, 森川信之, 藤原広行 : 2011 年東北 地方太平洋沖地震の強震動, 東日本大震災調査報告, 主要災害調査 No.48, pp.63-72, 2012.03 .

18）野津厚, 若井淳 : 東北地方太平洋沖地震の本震の記録, 港湾地域強震観 測年報(2011)，港湾空港技術研究所資料，No.1266，pp.16-27，2013.3.

19) 鹿嶋俊英, 小山信, 大川出: 平成 23 年(2011 年) 東北地方太平洋沖地震 における建物の強震観測記録, 建築研究資料, No.135, 2012.3.

20) 神山真: 2011 年東北地方太平洋沖地震における東北工業大学アレー強震 観測システムSmall-Titan による強震記録について（速報 Ver.1），35pp., 2011.4 .

21) 金子正洋, 片岡正次郎, 長屋和宏, 松岡一成：平成 23 年(2011 年) 東北 地方太平洋沖地震による強震記録, 国土技術政策須郷研究所資料, No.726, 227pp., 2013.2.

22) 日本建築学会東北支部災害調査連絡会 : 東北地方で観測された 2011 年 東北地方太平洋沖地震の建物・地盤系強震データ集 Ver.1.0 (CD-ROM), 2013.6.

23）東日本大震災に関する東北支部学術合同調査委員会 : 諸機関が観測した 地震動, 平成 23 年(2011 年) 東北地方太平洋沖地震災害調査報告書, pp.35-36, 2013.5 .

24) 翠川三郎, 三浦弘之 : 2011 年東北地方太平洋沖地震の地震・地震動につ いて, 地震工学研究レポート, 東京工業大学都市地震工学センター, No.118, pp.1-20, 2011.6 .

25) Rodriguez, V. and Midorikawa, S.: Applicability of the H/V spectral Ratio of 
microtremors in assessing site effects on seismic motion, Earthquake Engineering and Structural Dynamics, Vol.31, pp.262-279, 2002.

26) Rodriguez, V.: Applicability of Microtremor in Evaluating Site Characteristics of Ground Motion, 東京工業大学修士論文, 2000 .

27）翠川三郎, 野木淑裕: 深さ $30 \mathrm{~m}$ までの地盤の平均 $\mathrm{S}$ 波速度を深さの浅い データから推定する方法について, 日本地震工学会論文集, 第 15 巻, 第 2 号, pp.91-96, 2015.5.

28)防災科学技術研究所：J-SHIS 地震ハザードマップ, http://www.j-shis.bosai.go.jp/map/ (参照 2015.1.20) .

29) Kurahashi, S. and Irikura, K.: Short-Period Model of the $2011 \mathrm{Mw} 9.0$ Off the Pacific Coast of Tohoku Earthquake, Bull. Seism. Soc. Am., Vol.103, No.2B, pp.1373-1393, 2013.5.

30) Midorikawa, S., Miura, H. and Atsumi, T.: Strong Motion Records of the 2011 Tohoku Earthquake and its Attenuation Characteristics, Journal of Disaster Research, Vol.7, No.6, pp.693-700, 2012.12.

31）山口亮，翠川三郎：地盤の平均 $\mathrm{S}$ 波速度を用いた地盤増幅率の推定手法 の改良, 日本地震工学会論文集, 第 11 巻, 第 3 号, pp.85-101, 2011.8 .

32) 例えば, 翠川三郎：強震時にみられる地盤特性の非線形性, 地震, 第 46 巻, pp.207-216, 1993.9 .

33) 若井淳, 野津厚 : 広域の強震記録から推定される 2011 年東北地方太平 洋沖地震の表層地盤の非線形挙動, 日本地震工学会論文集, 第 12 巻, 第 4 号, pp.160-176, 2012.9.

34) 藤本一雄 : 東北地方太平洋沖地震の強震記録に基づく表層地盤増幅特性, 第 40 階地盤震動シンポジウム（2012）資料集，pp.29-36，2012.11.

35) 飯場正紀 : 限界耐力計算に於ける入力地震動・地盤増幅に関する技術的 背景，第 29 回地盤震動シンポジウム資料集，pp.23-46，2001.10.

36) Stewart, J.P. and Seyhan, E.: Semi-Empirical Nonlinear Site Amplification and its Application in NEHRP Site Factors, PEER Report No. 2013/13, Pacific Earthquake Engineering Research Center, U. C. Berkeley, 59 pp., 2013.11.. 


\title{
SITE CLASSIFICATION BY MICROTREMORS AND PRELIMINARY ANALYSIS OF SITE AMPLIFICATION DURING STRONG SHAKING FOR DIFFERENT SITE CLASSES
}

\author{
Yoshihiro NOGI*, Saburoh MIDORIKAWA** and Hiroyuki MIURA*** \\ * Formerly Grad. Stud., Dept. of Built Environment, Interdisciplinary Graduate School of Science and Technology, Tokyo Institute of Technology \\ ** Prof., Dept. of Built Environment, Interdisciplinary Graduate School of Science and Technology, Tokyo Institute of Technology, Dr.Eng. \\ *** Assoc. Prof., Dept. of Architecture, Graduate School of Engineering, Hiroshima Univ., Dr.Eng.
}

The 2011 off the Pacific coast of Tohoku Earthquake of Mw9.0 produced many strong motion records, owing to dense strong motion observation networks in Japan. About three thousands records are collected and complied. The records provide a unique opportunity to examine site amplifications in strong shaking level. The available site characteristics data for the records, however, are limited. The soil profile data are available at about 100 sites. For the other data, the available site information is geomorphologic classification from the nation-wide digital map, but it is rather crude for the site characterization. To strengthen the site characteristics data, microtremor measurements are conducted at about 500 strong motion sites in the high seismic intensity zone, as shown in Fig. 1. In the measurement, we use the system whose overall response is almost constant with ground velocity up to 2 seconds, as shown in Fig. 2. The H/V spectral ratios of microtremors for different NEHRP site classes (Table 1) are shown in Fig. 3. The following criteria are determined for site classification from the $\mathrm{H} / \mathrm{V}$ spectral ratio: 1) the site having the $\mathrm{H} / \mathrm{V}$ spectral ratio with higher amplitudes at periods 0.6 to $1.2 \mathrm{sec}$. with respect to those at periods 0.1 to $0.3 \mathrm{sec}$. is the class $\mathrm{E}$ (Fig.4), 2) the site having the H/V spectral ratio constant with periods is the class B (Fig. 5), and 3) the sites having the $\mathrm{H} / \mathrm{V}$ spectral ratios with larger and smaller amplitudes at periods of 0.3 to $0.8 \mathrm{sec}$. with respect to those at periods 0.1 to $0.2 \mathrm{sec}$. are the classes $\mathrm{D}$ and $\mathrm{C}$, respectively, and the site having the intermediate amplitude is the class $\mathrm{C}$ or D referring the geomorphologic information (Fig. 6). For the sites where the site class is determined from the velocity profile data, the accuracy of the estimated site class is checked. The overall accuracy is $77 \%$ by the proposed method as shown in Table 2, whereas the accuracy of estimations from the geomorphologic information is $51 \%$ as shown in Table 3. By using the criteria for site classification, the target strong motion sites are classified into 30 class B sites, 153 class C sites, 206 class D sites and 77 class E sites, as shown in Fig. 7 . Site effects on the strong motion records are preliminarily discussed from the average spectra for site classes B, C, D and E. The average spectrum with standard deviation for each class is shown in Fig.8. The velocity response spectra tend to be constant with period at class B. The spectral amplitudes become larger at site classes with slower $\mathrm{V}_{\mathrm{s} 30 .}$ At site class E, the amplitudes tend to be larger at around 1 second. As shown in Table 3, the average and standard deviation of the peak horizontal accelerations at class B are $0.45 \mathrm{~g}$ and $0.19 \mathrm{~g}$, respectively. The small deviation suggests that the shaking level inputted to the bedrock at the sites may not have large difference. Therefore, the ratio of the average spectrum at class $\mathrm{C}, \mathrm{D}$ or $\mathrm{E}$ with respect to that at class $\mathrm{B}$ is considered to be an approximate of site amplification. As shown in Fig. 9, the amplification of site classes C to B is almost one, but those of site classes D and $\mathrm{E}$ to $\mathrm{B}$ are larger at longer periods and smaller at shorter periods. The amplification is compared with the site amplification derived from weak motion records. The difference in both amplifications indicates effects of nonlinear soil response. 